Krzysztof Kozłowski

\title{
POLITYKA UNII EUROPEJSKIEJ WOBEC AZJI ŚRODKOWEJ: ANALIZA REALIZACJI STRATEGII NA RZECZ NOWEGO PARTNERSTWA Z AZJĄ ŚRODKOWĄ
}

\section{Wprowadzenie}

W corocznych ocenach oraz w pięcioletniej ewaluacji Rada Europejska uznała za zasadne kontynuowanie prac w ramach Strategii na rzecz Nowego Partnerstwa z Azją Środkową w formule przyjętej w 2007 r. ${ }^{1}$ Rada i Parlament Europejski stwierdziły, że strategia „sprawdziła się i pozostaje słuszna”. W zakresie osiągnięć wskazano zwłaszcza na postępy w zaznaczaniu obecności dyplomatycznej UE w regionie po 2007 r. (powołanie przedstawicielstw UE w Kazachstanie, Kirgistanie, Tadżykistanie i Uzbekistanie oraz Specjalnego Przedstawiciela UE dla Azji Środkowej, a także sukces europejskiej reakcji na wydarzenia 2010 r. w Kirgistanie) ${ }^{3}$. Odnotowano również, że cele strategii sformułowano trafnie i jako takie należy je podtrzymać w przyszłości (stabilność, bezpieczeństwo i zrównoważony rozwój regionu, stosunki handlowe i gospodarcze, połączenia energetyczne i transportowe, wzmocnienie dialogu na temat uniwersalnych wartości takich jak demokracja, poszanowanie praw człowieka i praworządność, wspólne wyzwania i zagrożenia, w tym zarządzanie granicami oraz walka $\mathrm{z}$ handlem narkotykami i ludźmi). Zarówno Parlament, jak i Rada deklarowały dalsze zaangażowanie w problemy regionu, kontynuację konsultacji

1 W polskiej naukowej literaturze etnograficznej i antropologicznej dominuje nazwa Azja Środkowa. W literaturze politologicznej spotkać można wymienne stosowanie Azja Środkowa i Centralna. Azja Środkowa w rozumieniu geograficznym, szerszym, sięga po Afganistan, Mongolię i część Pakistanu. W rozumieniu politycznym, węższym, jest utożsamiana z pięcioma republikami poradzieckimi: Kazachstanem, Kirgistanem, Tadżykistanem, Uzbekistanem i Turkmenistanem. W artykule stosowane jest ujęcie polityczne, co znajduje odzwierciedlenie w określeniu poradziecka Azja Środkowa.

2 Sprawozdanie w sprawie postępów w realizacji Strategii UE wobec Azji Środkowej, http://www.europarl. europa.eu/sides/getDoc.do?pubRef=-//EP//TEXT+REPORT+A7-2011-0338+0+DOC+XML+V0//PL

3 W 2010 r. w Kirgistanie doszło do masowych wystąpień społecznych, które przerodziły się w parazbrojne obalenie prezydenta Kurmanbeka Bakijewa. W tle wydarzeń pozostawał konflikt między północą a południem państwa oraz między ludnością uzbecką i kirgiską. Więcej: K. Kozłowski, Kolory Rewolucji, Poltext, Warszawa 2012, s. 84. 
z państwami Azji Środkowej, w szczególności na wysokim szczeblu, pomoc rozwojową i chęć dialogu na temat bezpieczeństwa regionalnego i energetycznego, demokratyzacji i praw człowieka.

Powyższe deklaracje są jednocześnie bardzo budujące i niezwykle ciekawe. Budujące, ponieważ sygnalizują chęć głębokiego zaangażowania instytucji UE w pomoc państwom rozwijającym się, są przejawem unijnych ambicji bycia graczem o charakterze globalnym oraz zrozumienia dla koncepcji zrównoważonego rozwoju. Ciekawe, ponieważ trudno znaleźć ich wymierne potwierdzenie. Wskazaną w dokumentach instytucję Specjalnego Przedstawiciela UE zlikwidowano ${ }^{4}$, przedstawicielstwa UE mają niedoprecyzowane funkcje, co wymiernie ogranicza ich efektywność ${ }^{5}$, a pomoc unijna dla państw regionu jest niezauważana nawet przez urzędników unijnych wyznaczanych do kontroli jej wykorzystania ${ }^{6}$. Choć nie można zaprzeczyć, że konsultacje na wysokim szczeblu stały się trwałym elementem krajobrazu politycznego regionu, ich efekty trudno skonkretyzować, a uściski dłoni unijnych dyplomatów i najbardziej autorytarnych przywódców na świecie są przez niektórych komentatorów uznawane za szkodliwe wizerunkowo dla unijnej Soft Power ${ }^{7}$. Na obronę autorów strategii należy wskazać, że pewne jej mankamenty dostrzeżono. Dotyczyło to zwłaszcza dysproporcji między obszerną listą celów a relatywnie skromnym finansowaniem oraz braku wystarczającej koordynacji działań państw członkowskich w regionie ${ }^{8}$. Brak podjęcia konkretnych kroków mających usunąć te słabości skłania jednak do refleksji nad sensownością nie tylko poszczególnych części strategii, ale nad jej całością oraz nad kierunkiem regionalnej polityki unijnej.

Celem opracowania jest ocena trafności, efektywności oraz perspektyw polityki UE wobec Azji Środkowej. Artykuł nie dotyczy kwestii technicznej obsługi strategii, tj. oceny efektywności mechanizmów finansowania projektów czy ich kontroli. Co najwyżej skromne osiągnięcia w okresie obowiązywania strategii zmuszają do podniesienia bardziej ogólnych pytań o polityczne cele i środki wykorzystywane przez Unię w regionie. Obserwując rozwój relacji między Unią Europejską a państwami poradzieckiej Azji Środkowej, trudno nie ulec wrażeniu, że UE, tworząc strategię, nie

4 J. Boonstra, Is the EU Downscaling Political Engagement in Central Asia?, „EUCAM Commentary” February 2014, No. 23.

5 N. Melvin, The EU Needs a New Value-Based Realism for its Central Asia Strategy, „EUCAM Policy Brief” 2012, No. 28, s. 3.

6 Więcej przykładów: G. Gavrilis, Central Asia’s Border Woes \& the Impact of International Assistance, Central Eurasia Project, Open Society Foundation, New York, May 2012.

7 The not so welcome guest: Who invited Islam Karimov to Brussels?, „The European Voice” 7 January 2011, http://www.europeanvoice.com/article/imported/the-not-sowelcome-guest/70077.aspx

8 V. Axyonova, EU Human Rights and Democratization Assistance to Central Asia: In Need ofFurther Reform, „EUCAM Policy Brief” 2012, No. 22. 
zadała sobie dwóch kluczowych pytań. Pierwsze brzmi: dlaczego Unia Europejska chce się w ogóle angażować w regionie zdominowanym przez autorytarne reżimy uwięzione w geopolitycznym klinczu między Federacją Rosyjską a Chińską Republiką Ludową? Drugie, nie mniej istotne, to w jaki sposób chce te cele osiągnąć? Niezależnie od samooceny unijnej biurokracji UE w poradzieckiej Azji Środkowej UE nie wykorzystuje w adekwatnym stopniu własnego potencjału międzynarodowego, a podejmowane przez jej przedstawicieli działania są nieraz szkodliwe zarówno w wymiarze nieefektywnego zarządzania zasobami własnymi, jak i uszczerbku wizerunkowego $\mathrm{w}$ relacjach zewnętrznych. W praktyce stosunków politycznych $\mathrm{w}$ regionie widać wyraźnie, że unijne ambicje przerosły realne możliwości oddziaływania. O ile dążenia do stania się graczem o znaczeniu światowym w istotnej geopolitycznie części globu są zrozumiałe, mijające siedem lat od uchwalenia strategii skłania do rewaluacji nie tyle technicznych instrumentów jej realizacji, ile jej politycznych założeń.

\section{Strategia UE wobec Azji Środkowej - zarys uwarunkowań regionalnych}

W analizach politologicznych dotyczących obszaru poradzieckiej Azji Środkowej kluczowym procesem geopolitycznym warunkującym sytuację $\mathrm{w}$ regionie jest Nowa Wielka Gra9 ${ }^{9}$. Proces ten ma obejmować z jednej strony próby zachowania kontroli Federacji Rosyjskiej nad państwami poradzieckimi po zakończeniu okresu bezpośredniego zwierzchnictwa ZSRR, z drugiej - poszerzanie regionalnych wpływów przez podmioty międzynarodowe konkurujące ze stroną rosyjską, głównie Stany Zjednoczone oraz Chińską Republikę Ludową ${ }^{10}$. Walka o wpływy geopolityczne toczy się w obszarze niezwykle istotnym dla pozycji międzynarodowej państw aspirujących do globalnego oddziaływania na stosunki międzynarodowe. Wyjątkowa rola Azji Środkowej wynika ze strategicznego położenia (granice z Rosją, zachodnimi

9 A. Rashid, The New Great Game - The Battle for Central Asia’s Oil, „Far Eastern Economic Review” 10 April 1997.

${ }^{10} \mathrm{~W}$ tej kwestii wśród polskich specjalistów wyraźnie słychać dwugłos, zwłaszcza w kontekście konfliktu gruzińskiego. Jedni uważają, że mamy do czynienia z Rosją neoimperialną, dążącą do odbudowy pozycji z czasów ZSRR. Inni są odmiennego zdania, twierdząc, że Federacja Rosyjska traci wpływy i coraz bardziej nerwowo stara się utrzymać swoją obecną pozycję. Por. W. Ross, Stosunki chińsko-rosyjskie. Historia, wspótczesność, perspektywy, w: Chińska Republika Ludowa we wspótczesnych stosunkach międzynarodowych, red. P. Ostaszewski, Oficyna Wydawnicza SGH, Warszawa 2011; K. Strachota, Kaukaz Poludniowy i Azja Centralna po wojnie rosyjsko-gruzińskiej - konsekwencje geopolityczne, „Komentarze OSW” 25 września 2008, nr 10, http://www.osw.waw.pl/pl/publikacje/komentarze-osw/2008-09-25/kaukaz-poludniowyi-azja-centralna-po-wojnie-rosyjsko-gruzinski (dostęp 28.09.2009). 
Chinami, Afganistanem i Iranem, Morzem Kaspijskim) oraz znajdujących się na jej terytorium bogatych zasobów surowców energetycznych wraz z coraz bardziej rozbudowywaną infrastrukturą ich przesyłu.

W kontekście rozważań o Nowej Wielkiej Grze w Azji Środkowej często dochodzi do redukcji roli państw poradzieckich regionu do przedmiotów rozgrywki politycznej między mocarstwami. Jest to jednak tendencja błędna. Państwa Azji Środkowej oczywiście nie dysponują nawet zbliżonym potencjałem do któregokolwiek z wymienionych wcześniej podmiotów globalnych, jednak ich umiejętności wykorzystywania okoliczności międzynarodowych i często wzajemnie sprzecznych interesów mocarstw pozwoliły im wzmocnić własną niezależność wewnętrzną i zbudować samodzielną podmiotowość w stosunkach międzynarodowych.

Poradziecka Azja Środkowa obejmuje pięć republik powstałych w 1991 r. po rozpadzie ZSRR: Kazachstan, Kirgistan, Uzbekistan, Tadżykistan i Turkmenistan. Kazachstan, największa $z$ nich, jest jednocześnie gospodarczym liderem regionu. Dysponując dużymi zasobami ropy naftowej, jest istotnym elementem w regionalnej rozgrywce o dostęp do surowców energetycznych, toczącej się między Federacją Rosyjską, Stanami Zjednoczonymi i ChRL. O sukcesie tych starań najlepiej świadczy, że kazachstańska ropa może już być eksportowana do Rosji, państw zachodnich z pominięciem rosyjskiego tranzytu, jak również do Chin. Drugim państwem posiadającym najwięcej złóż surowców energetycznych, tym razem gazu ziemnego, jest Turkmenistan. Jego władze aktywnie poszukują możliwości nawiązania współpracy międzynarodowej, która mogłaby uniezależnić państwo od dominacji rosyjskiej w zakresie przesyłu gazu. ChRL stara się to aktywnie wykorzystać, czego wyrazem jest uruchomienie gazociągu do Chin w 2009 r. Kirgistan i Tadżykistan to najuboższe państwa Azji Środkowej. Tadżykistan po wojnie domowej w latach 90. ponownie stoi przed poważnymi problemami wewnętrznymi, tym razem o charakterze gospodarczym. Pojawiły się nawet głosy, że jest na skraju rozpadu państwowości ${ }^{11}$. Kirgistan, wydawało się najbardziej demokratyczne państwo w regionie, na przestrzeni ostatniej dekady przeszedł dwie gwałtowne zmiany władzy: rewolucję tulipanów w 2005 i przewrót w $2010 \mathrm{r}$. Targają nim również poważne spory etniczne. W $2010 \mathrm{r}$. doszło do kolejnych (po latach 90.) zamieszek i pogromów ludności uzbeckiej na południu $\mathrm{kraju}^{12}$. Uzbekistan, dysponujące największą populacją państwo regionu graniczące ze wszystkim nowymi republikami poradzieckimi, rządzony twardą ręką przez I. Karimowa ma z kolei duże problemy z antysystemowymi ugrupowaniami muzułmańskimi,

${ }^{11}$ M. Falkowski, Tadżykistan w obliczu kryzysu państwowości, „Komentarze OSW” 2009, nr 22.

12 K. Kozłowski, Iluzje rewolucji. Rewolucja róż, rewolucja pomarańczowa, rewolucja tulipanów, Oficyna Wydawnicza SGH, Warszawa 2010, s. 119-145. 
walczącymi z reżimem na terytorium Kotliny Fergańskiej, swoistego korytarza z Afganistanu do poradzieckiej Azji Środkowej ${ }^{13}$. Jego położenie pozwala mu jednak odgrywać istotną rolę w tranzycie surowców energetycznych, jak również w polityce bezpieczeństwa regionu ${ }^{14}$.

O ile na początku lat 90 . wszystkie wymienione państwa były mało aktywne na arenie międzynarodowej, o tyle obecnie sytuacja uległa poważnym zmianom. Zwłaszcza Kazachstan, Turkmenistan i Uzbekistan starają się rozgrywać interesy Rosji, USA i ChRL z myślą o powiększaniu zakresu własnej swobody działania i kapitalizacji możliwie dużych zysków gospodarczych i politycznych. Na przykład po wydarzeniach 11 września 2001 r. wszystkie państwa Azji Środkowej dokonały zbliżenia politycznego z państwami NATO, równoważąc w ten sposób, choć tylko tymczasowo, rosyjskie wpływy militarne. Najdalej w tym względzie posunęły się Kirgistan i Uzbekistan, umożliwiając utworzenie na swoich terytoriach baz wojskowych USA i NATO w ramach działań w Afganistanie, korzystając finansowo i politycznie na zbliżeniu z Zachodem. Z kolei w ramach Szanghajskiej Organizacji Współpracy (Turkmenistan pozostaje poza nią) wykorzystując polityczne poparcie ChRL, były później w stanie pozostać asertywne wobec ekspansji amerykańskiej (żądanie określenia czasu pobytu wojsk amerykańskich w regionie w 2005 r. oraz poparcie Uzbekistanu skonfliktowanego z USA na tle wydarzeń w Andiżanie w maju 2005 r.), jak również trzy lata później wobec Rosji (nie przychyliły się do uznania niepodległości Abchazji i Osetii Południowej po wojnie gruzińsko-rosyjskiej). Jednocześnie wszystkie republiki nie rezygnują ze współpracy w zakresie bezpieczeństwa z Federacją Rosyjską (choć Uzbekistan wystąpił z Organizacji Układu o Bezpieczeństwie Zbiorowym w 2012 r., a Kazachstan lawiruje politycznie w kwestiach związanych z koncepcjami eurazjatyckimi Rosji), która pomimo rozwoju analogicznej współpracy w ramach SOW wciąż odgrywa kluczową rolę w sytuacji militarnej w regionie. Stanowi to z kolei swoistą przeciwwagę do ekspansji gospodarczej Chin ${ }^{15}$.

Analizując sytuację w poradzieckiej Azji Środkowej, nie wolno lekceważyć aktorów lokalnych. Wszystkie pięć młodych republik świetnie pamiętają lata absolutnej hegemonii rosyjskiej. Dwie dekady suwerenności otworzyły nowe perspektywy przed lokalnymi elitami politycznymi, które nie są skore do zamienienia jednej obcej dominacji na inną. Istotną rolę odgrywają w tym zakresie historyczne doświadczenia

\footnotetext{
${ }^{13}$ M.B. Olcott, Islam and Fundamentalism in Independent Central Asia, w: Muslim Eurasia: Conflicting Legacies, red. R. Yaakov, Frank Cass, London 1995, s. 23.

14 Obszerne omówienie sytuacji wewnętrznej w poszczególnych państwach poradzieckiej Azji Środkowej po uzyskaniu niepodległości można znaleźć w serii monografii zbiorowych Współczesna Azja Centralna pod red. T. Bodio.

${ }^{15}$ K. Kozłowski, Iluzje rewolucji..., op.cit., s. 154-165.
} 
ludów regionu odwiecznie lawirujących między światowymi potęgami ${ }^{16}$. Żaden z poradzieckich reżimów Azji Środkowej nie jest skłonny do rezygnacji choćby z części dorobku krótkiej niepodległości, a zainteresowanie wielu „wielkich tego świata” wcześniej politycznie niedostępnym regionem dostarcza licznych okazji do rozgrywania ich interesów na korzyść lokalnych elit politycznych.

Oceniając dotychczasowy kontekst geopolityczny realizacji strategii UE wobec Azji Środkowej, należy przede wszystkim stwierdzić, że pozycja Unii Europejskiej względem innych graczy regionalnych jest relatywnie słabsza. Unia Europejska nie dysponuje argumentami Hard Power jak USA czy Rosja (obecność militarna), powiązaniami społecznymi, jakimi wciąż cieszy się Federacja Rosyjska (spuścizna poradziecka), czy zasobami finansowymi choćby po części porównywalnymi z Chinami (największy inwestor w regionie). Biurokratyczne struktury unijne nie są wystarczająco elastyczne, by szybko reagować na pojawiające się zagrożenia (wbrew pozytywnej samoocenie w przypadku każdego kryzysu humanitarnego w regionie w porównaniu z innymi graczami reakcja Unii była zawsze spóźniona), ani wykorzystywać nadarzające się okazje do zbliżenia (co potwierdza casus turkmeński w 2008 r.) ${ }^{17}$. Jest to też region zdominowany przez reżimy autorytarne, bez tradycji demokratycznych w zachodnim rozumieniu ${ }^{18}$. Duże odległości i relatywnie trudna dostępność geograficzna oraz wciąż silne lokalne tradycje połączone z miejscowymi formami islamu zmniejszają też skuteczność promocji czy choćby tylko ekspozycji zachodnich wzorców politycznych. Świadomość tych słabości jest warunkiem wstępnym dla realistycznej oceny unijnych możliwości oddziaływania w regionie. Jest też pierwszym krokiem w dopasowaniu ambicji UE do politycznej rzeczywistości poradzieckiej Azji Środkowej.

\section{Strategia UE wobec Azji Środkowej - ocena implementacji}

Wbrew stwierdzeniom Rady Europejskiej dotychczasowe rezultaty zaangażowania UE w Azji Środkowej rozczarowują. Można się wręcz spotkać z ocenami, że UE dała sobie narzucić styl i tok rozmów przez lokalnych autokratycznych przywódców,

\footnotetext{
16 Obszerne rozważania na ten temat patrz K. Collins, Clan Politics and Regime Transition in Central Asia, Cambridge University Press, New York 2006.

17 Casus opisany w dalszej części artykułu.

${ }^{18}$ Należy zaznaczyć, że w rozmowach z mieszkańcami regionu większość z nich wskazuje na miejscowe tradycje tzw. demokracji stepowej - kolektywnego zarządzania zasobami plemion i klanów z czasów poprzedzających kolonizację rosyjską. Więcej S. Zapaśnik, Demokracja a kultury tradycyjne w Azji Środkowej, w: Jednostka i społeczeństwo w Azji Wschodniej, red. A.W. Jelonek, Wydawnictwo Adam Marszałek, Toruń 2007.
} 
którzy umiejętnie wykorzystali unijne ambicje do własnych celów ${ }^{19}$. Zwłaszcza w kontekście oceny postępów unijnych na płaszczyznach demokratyzacji i praw człowieka, współpracy energetycznej czy bezpieczeństwa regionalnego trudno się z takim wnioskiem nie zgodzić. W dużej mierze należy tę sytuację wiązać z nietrafnym doborem instrumentów realizacji unijnych założeń.

Podstawowym narzędziem działania UE było rozpoczęcie dialogu politycznego z władzami republik poradzieckich w ramach wyznaczonych w strategii celów, którymi są: stabilność, bezpieczeństwo i zrównoważony rozwój regionu, rozwój stosunków handlowych i gospodarczych, rozwój połączeń energetycznych i transportowych, demokratyzacja regionu, poszanowanie praw człowieka i praworządność, wspólne wyzwania i zagrożenia bezpieczeństwa, w szczególności poprawa kontroli granic i walka $z$ handlem narkotykami oraz ludźmi. Polityka dialogu i współpracy z władzami centralnymi państw regionu jest jednak oparta na błędnym założeniu ich reprezentatywności dla miejscowych społeczeństw. W praktyce współpraca z reżimem neopatrymonialnym, a do tej grupy należą wszystkie poradzieckie reżimy Azji Środkowej, zawsze oznacza współpracę z elitami władzy bez możliwości kontrolowanego przełożenia jej wyników na sytuację społeczną. De facto pomoc unijna jest często traktowana jako kolejny zasób, który zostaje rozdysponowany przez rządzących między swoich zwolenników ${ }^{20}$.

Kolejnym istotnym przeoczeniem było nadanie celom strategii charakteru transformacyjnego. O ile promowanie reform i współpraca w procesie kształtowania nowych instytucji jest skuteczna na etapie konstytuowania się nowej państwowości, o tyle wszystkie miejscowe reżimy autorytarne skonsolidowały się już w latach 90 . Z tego powodu, analizując okres obowiązywania strategii, trudno znaleźć jakiekolwiek potwierdzenie postępów, które można by było powiązać z aktywnością unijną. Dotyczy to zwłaszcza ochrony praw człowieka lub demokratyzacji lokalnych reżimów, standardów rządzenia, rozwoju demokracji czy budowy społeczeństwa obywatelskiego. Wręcz przeciwnie, jedyne zmiany, jakie można odnotować, to regres w zakresie wszystkich wymienionych zagadnień. Freedom House wskazuje, że w okresie obowiązywania strategii w Kazachstanie, Kirgistanie i Uzbekistanie we wszystkich wskazanych sferach osiągano międzynarodowo najniższe standardy lub wręcz sytuacja się pogorszyła ${ }^{21}$. Warto zauważyć, że raporty organizacji, choć niepowiązanej

${ }^{19}$ N. Melvin, op.cit., s. 5.

${ }^{20}$ Ze względu na relatywnie najdalej posunięty proces demokratyzacji w regionie najlepiej dokumentowanych przykładów tego mechanizmu dostarcza polityka kirgiska - zwłaszcza upadek prezydenta Askara Akajewa w 2005 r. Podobne mechanizmy uruchomił również jego następca, K. Bakijew, obalony w $2010 \mathrm{r}$. Więcej: K. Kozłowski, Rewolucja Tulipanów. Geneza, przebieg, konsekwencje, Elipsa, Warszawa 2009.

${ }_{21}$ Notowania poszanowania praw i wolności politycznych i obywatelskich Freedom House dla Azji Środkowej: http://www.freedomhouse.org/regions/eurasia\#.VARkx6OTCSo (dostęp 1.09.2014). 
$\mathrm{z}$ instytucjami unijnymi, wskazują wprost na zagadnienia wymienione w strategii, tj.: niepokojąco niski poziom rozwoju społeczeństwa obywatelskiego, standardów rządzenia, procedur i praktyk wyborczych czy niezależności sędziowskiej. Podobne wnioski prezentuje Transparency International, stwierdzając brak postępów lub pogorszenie sytuacji w zakresie zwalczania korupcji ${ }^{22}$. Z kolei Reporterzy bez Granic stwierdzają pogorszenie sytuacji w zakresie wolności mediów we wszystkich państwach regionu ${ }^{23}$. W okresie obowiązywania strategii państwa Azji Środkowej znalazły się wśród globalnych liderów w zakresie ograniczania wolności słowa.

Mechanizm dialogu nie przyniósł zamierzonych rezultatów nie tylko w zakresie zagadnień powszechnie postrzeganych jako kluczowe dla polityki zewnętrznej UE, jak promocja demokracji i ochrona praw człowieka. Nieefektywność UE jest również widoczna w wymiarze bezpieczeństwa energetycznego strategii, powszechnie przez specjalistów uznawanego za kluczowy w odniesieniu do regionu ${ }^{24}$. Wynika to $\mathrm{z}$ asymetrycznej i niekorzystnej dla UE natury takiego dialogu z państwami autorytarnymi. W praktyce politycznej podmiot demokratyczny nigdy nie będzie dysponował elastycznością działania porównywalną ze scentralizowanym reżimem autokratycznym.

Strategia była formułowana w okresie bezpośrednio po pierwszej wojnie gazowej między Federacją Rosyjską a Ukrainą, która doprowadziła do ograniczenia dostaw gazu ziemnego do Europy w zimie 2006 r. Reakcją UE na powstałe wtedy zagrożenie dla bezpieczeństwa energetycznego jej państw członkowskich, w szczególności Europy Wschodniej i Południowej, była inicjatywa utworzenia tzw. korytarza południowego, mającego dostarczać gaz kaspijski na rynek europejski. Centralą rolę odgrywał w nim rurociąg Nabucco, który miał być wypełniony głównie turkmeńskim gazem. Rezerwy dla projektu miały być pozyskane w ramach współpracy z Kazachstanem i Azerbejdżanem ${ }^{25}$. Po wprowadzeniu w życie strategii instytucje europejskie podjęły duże wysiłki dyplomatyczne w celu poprawy relacji z Turkmenistanem, włączając w to uzgodnienie i podpisanie długo odkładanej Umowy o Partnerstwie i Współpracy ${ }^{26}$. Zmieniono również mandat Specjalnego Przedstawiciela UE, tak by obejmował kwestie bezpieczeństwa energetycznego. Turkmenistan był

${ }^{22}$ Notowania Corruption Perceptions Index, Transparency International dla Azji Środkowej: http://www. transparency.org/research/cpi/ (dostęp 1.09.2014).

${ }^{23}$ Notowania World Press Freedom Index dla Azji Środkowej, Reporterzy bez Granic: http://rsf. org/index2014/en-eastern-europe.php (dostęp 1.09.2014).

${ }^{24}$ Ł. Gacek, Azja Centralna w polityce energetycznej Chin, Wydawnictwo Uniwersytetu Jagiellońskiego, Kraków 2013, s. 23-25.

${ }^{25}$ Oficjalna witryna Trans-European Energy Network: http://ec.europa.eu/energy/infrastructure/index en.htm,Nabucco opatrzono symbolem NG3 (dostęp 1.09.2014).

${ }^{26}$ J. Boonstra, EU Central Asia Policy: Steady as She Goes, „Central Asia Policy Brief” August 2012, No. 4 , s. 2. 
celem licznych wyjazdów wysokich urzędników UE, włączając różnych komisarzy, co ostatecznie doprowadziło do podpisania Porozumienia o Współpracy w Kwestiach Energetycznych między UE a Turkmenistanem w 2008 r. ${ }^{27}$ Kiedy jednak rok później powstała szansa szybkiego nawiązania współpracy, procedury unijne nie mogły się równać elastycznością z chińskim know-how we współpracy energetycznej ${ }^{28}$. W $2014 \mathrm{r}$. Turkmenistan wciąż wiążąco nie zobowiązał się do sprzedaży gazu przez korytarz południowy, a problem transportu surowca z Kazachstanu poprzez Morze Kaspijskie wciąż pozostaje nierozwiązany. W tym samym czasie Chiny dysponują już gazociągiem z Turkmenistanu oraz współpracują z państwami regionu nad kolejnymi. Wiele wskazuje na to, że zanim projekt Nabucco zobaczył światło dzienne, już przeszedł do historii ${ }^{29}$.

Podobnie można oceniać współpracę w zakresie bezpieczeństwa regionalnego. Można mieć uzasadnione wrażenie, że jednym z głównych impulsów do powstania strategii była refleksja państw Unii nad wsparciem dla wojsk państw członkowskich w ramach ISAF, co jest blisko powiązane ze stabilnością pobliskich państw Azji Środkowej $^{30}$. Cel ten urzeczywistniano ponownie $\mathrm{w}$ formie dialogu $\mathrm{z}$ reżimami politycznymi w regionie, w szczególności w drodze spotkań na wysokim szczeblu. Spotkania

${ }^{27}$ N. Melvin, op.cit., s. 5 .

${ }^{28}$ W wyniku wojny gazowej między Turkmenistanem a Federacją Rosyjską w 2009 r. władze w Aszchabadzie zwiększyły wysiłki mające na celu nawiązanie współpracy z Unią Europejską (czego dotyczyła wizyta ministra spraw zagranicznych Turkmenistanu Raszyda Meredowa w Brukseli 3 czerwca 2009 r.) i Chinami (wizyta wicepremiera Turkmenistanu Taczberdy Tagijewa tydzień później w Pekinie). O ile Unia Europejska nie była w stanie wykorzystać okazji, ChRL przejęła inicjatywę i pośrednio zaangażowała się w konflikt turkmeńsko-rosyjski, udzielając Turkmenistanowi kredytu w wysokości 4 mld USD. Już 24 czerwca 2009 r. podczas wizyty wicepremiera Chin Li Keqianga w Aszchabadzie turkmeński koncern gazowy Turkmengaz oraz Chiński Państwowy Bank Rozwoju podpisały umowę kredytową w wysokości 4 mld USD. Zgodnie $\mathrm{z}$ zapowiedziami władz turkmeńskich ma on być przeznaczony na zagospodarowanie największego turkmeńskiego złoża gazowego - Południowy Jolotan. Należy zwrócić uwagę, że jest to kolejna umowa po kontrakcie na dostawy $30 \mathrm{mld} \mathrm{m}^{3} \mathrm{z} 2008 \mathrm{r}$. O ile pod koniec roku UE była na etapie inicjowania dialogu, to $\mathrm{w}$ tym samym czasie trwały już prace nad gazociągiem do ChRL. Warto dodać, że w tym zakresie Chiny zdążyły już dojść do porozumienia z Kazachstanem i Uzbekistanem jako państwami tranzytowymi. A. Jarosiewicz, K. Strachota, Nowa Wielka Gra - przesilenie?, „Komentarze OSW” 2009, nr 26.

${ }_{29}$ Projekt jest nierealny nie tylko z powodu przejęcia przez ChRL jego źródeł surowcowych. W świetle nowych odkryć złóż gazu i ropy w geograficznie bliższym Azerbejdżanie oraz tureckich prac nad rurociągami transanatolijskimi (TANAP) powstała politycznie bardziej realna oraz ekonomicznie bardziej opłacalna alternatywa dla Nabucco. Jednocześnie spory Azerbejdżanu z państwami Azji Środkowej na tle tranzytu surowców energetycznych wydatnie utrudniają pozyskanie gazu z Turkmenistanu, jeszcze bardziej podkopując realne perspektywy osiągnięcia porozumienia w sprawie gazociągu transkaspijskiego. De facto turkmeński gaz nie jest już nawet niezbędny do rozpoczęcia prac gazociągu TANAP, a starania europejskie o przeciwważenie rosyjskich inicjatyw energetycznych w Azji Środkowej okazały się bez wyjątku nie tylko nieudane, ale ostatecznie również bez praktycznego znaczenia.

${ }^{30} \mathrm{Na}$ potwierdzenie tej tezy można przytoczyć fakt, że na pierwszy plan we współpracy UE w wymiarze bezpieczeństwa z regionem wysuwają się tu starania niemieckiej prezydencji o unormowanie relacji z Uzbekistanem w kontekście użytkowania bazy lotniczej w Termez do wspierania niemieckich oddziałów stacjonujących na północy Afganistanu. 
okazały się jednak w dwojaki sposób krępujące wizerunkowo. Po pierwsze, przedstawiciele UE wymieniali uściski dłoni z politykami odpowiedzialnymi za stosowanie przemocy na globalnie rzadko spotykaną skalę wobec obywateli własnych państw. Po drugie, o ile przywódcy państw Azji Środkowej wyrażali chęć dyskusji o zagrożeniach bezpieczeństwa, jakie stanowią dla nich międzynarodowy terroryzm i ekstremizm czy przyszłość Afganistanu, o tyle nie znaleziono z nimi wspólnego języka $\mathrm{w}$ kwestii ich własnej roli w kreowaniu regionalnych zagrożeń bezpieczeństwa ${ }^{31}$. Takie podejście należy uznać za co najmniej kontrowersyjne. Przede wszystkim same reżimy Azji Środkowej są w dużej mierze odpowiedzialne za niestabilność regionu i niską jakość bezpieczeństwa jego mieszkańców. Praktycznie wszystkie przypadki regionalnych eksplozji przemocy nie wynikają z zagrożeń zewnętrznych, ani nie są niekontrolowanymi konsekwencjami demokratyzacji, jak starają się to przedstawić miejscowe władze. Są raczej konsekwencjami słabości lokalnych autorytarnych reżimów, jak w przypadku Kirgistanu w 2005 czy 2010 r., Tadżykistanu w 2010 czy 2012 r., lub wprost represji ze strony państwa, jak w Kazachstanie w 2011 r. czy prawdopodobnie w Uzbekistanie w $2005 \mathrm{r}^{32}$

Propozycje instytucjonalizacji dialogu na wysokim szczeblu z państwami regionu w przyszłości ze strony Rady Europejskiej sprawiają wrażenie, że UE jest otwarta na kontynuację rozmów o agendzie bezpieczeństwa w przytłaczającej mierze jednostronnie definiowanej przez autorytarnych przywódców Azji Środkowej. W konsekwencji dialog z przywódcami państw regionu nie dał zadowalających efektów ani w wymiarze poprawy bezpieczeństwa granic (cytując jednego z obserwatorów, „trudno na podstawie oceny jakości działań ocenić, czy dana placówka graniczna była objęta pomocą czy też nie"33), ani w zakresie podniesienia standardów bezpieczeństwa mieszkańców państw Azji Środkowej ${ }^{34}$. Na korzyść instytucji europejskich zaangażowanych we współpracę w zakresie bezpieczeństwa regionalnego można

31 Powszechnym w regionie tłumaczeniem wybuchów społecznego niezadowolenia jest ekstremizm, separatyzm lub terroryzm pochodzenia zewnętrznego. W rzeczywistości jednak, jak pokazują przykłady tadżyckiej wojny domowej w latach 90., kolejne przewroty i konflikty etniczne w Kirgistanie, walka ze zbrojną opozycją w Uzbekistanie, stłumienie wystąpień w 2012 r. w Kazachstanie czy totalitarna kontrola obywateli w Turkmenistanie, duża część, jeśli nie większość zagrożeń bezpieczeństwa w państwach regionu ma charakter endemiczny, a na jej tle odnaleźć można symptomy walki o władzę.

${ }^{32}$ Więcej: A. Cooley, The New Great Game in Central Asia: Geopolitics in a Post-Western World, „Foreign Affairs" 2012, No. 4.

33 G. Gavrilis, op.cit., s. 25.

${ }^{34}$ Najlepszym przykładem jest definiowanie konfliktu uzbecko-kirgiskiego na południu Kirgistanu w kategoriach etnicznych, czy jednoznaczne nazywanie wydarzeń w Andiżanie w 2005 r. masakrą ludności cywilnej. W pierwszym przypadku mamy do czynienia z konfliktem na tle dysproporcji socjalnych między bogatymi i dobrze sytuowanymi Uzbekami będącymi w posiadaniu większości własności ziemi w regionie, w drugim nawet raporty NATO wskazują na niekontrolowany wybuch walk wewnętrznych. Takie interpretacje świadczą o braku znajomości realiów politycznych państw poradzieckiej Azji Środkowej. 
jedynie dodać, że podobnie rozczarowujące rezultaty osiągnęły inne organizacje, jak OBWE i ONZ, czy zaangażowane regionalnie państwa, jak USA i Federacja Rosyjska. W ocenach politycznych takie stwierdzenia są jednak co najwyżej pocieszające.

\section{Strategia UE wobec Azji Środkowej - nadchodzące wyzwania}

W obliczu braku zamierzonych efektów Unia Europejska, jeśli nie ma powtórzyć wcześniejszych błędów, musi wypracować nowe podejście do poradzieckich republik Azji Środkowej. Należy jednak zauważyć, że rewaluacja dotychczasowych założeń i metod działania powinna być oparta nie tylko na analizie dotychczasowych niepowodzeń, ale również wypływać z faktu, że region stoi w obliczu zmian, które mogą znacząco zmienić jego polityczny i ekonomiczny obraz. Czynniki, które mogą przyczynić się do istotnego, jeśli nawet nie konstytutywnego przeobrażenia sytuacji geopolitycznej w regionie, to przede wszystkim wycofanie wojsk koalicji zachodniej z Afganistanu, zmieniające się relacje między podmiotami regionalnymi oraz zmiana władzy w poszczególnych państwach regionu. W kontekście przeobrażeń politycznych nie wolno też zapomnieć o równolegle zachodzących zmianach na światowych rynkach surowców energetycznych (upowszechnienie technologii wydobycia gazu łupkowego oraz LNG), które mogą znacząco wpłynąć na atrakcyjność gospodarczą regionu. Wobec dotychczasowych niepowodzeń politycznych antycypowanie zmiany jest z pewnością dużym wyzwaniem dla aparatu unijnego. Nowe rozdanie w Wielkiej Grze, w której Unia Europejska od 1991 r. najwyraźniej nie umie się odnaleźć, może dać jej jednak szansę na poprawę własnej sytuacji.

Oceniając dynamikę przemian politycznych w Azji Środkowej, można stwierdzić, że koniec roku 2015 będzie istotną cezurą polityczną dla wszystkich państw regionu. Wynika to przede wszystkim z faktu planowanego do tego czasu wycofania wojsk koalicji antyterrorystycznej z pobliskiego Afganistanu. W realiach okolicznych republik poradzieckich oznacza to istotny spadek zaangażowania USA w zapewnianie bezpieczeństwa regionalnego. To z kolei może się przełożyć na wzrost zagrożeń asymetrycznych, mniejszą stabilność państw poradzieckich oraz wymierny wzrost znaczenia innych, już niedemokratycznych mocarstw zaangażowanych w regionie - ChRL i Rosji.

Strategia UE wobec Azji Środkowej została wprowadzona w życie w relatywnie spokojnych i sprzyjających jej warunkach strategicznych. Zaangażowanie NATO w Afganistanie pociągnęło za sobą militarną obecność państw zachodnich w regionie. 
Oznaczało to objęcie regionu parasolem bezpieczeństwa sięgającego od Afganistanu do Azji Środkowej. Tym samym rola UE mogła być ograniczona do miękkiego wymiaru bezpieczeństwa: poprawy kontroli granic, zwalczania przestępczości zorganizowanej, dyplomatycznego wsparcia dla operacji afgańskiej.

Obecnie jednak sytuacja ulega przeobrażeniu. Chociaż USA prawdopodobnie wypracują jakąś formułę obecności wojskowej w Afganistanie, będzie ona istotnie zmniejszona i różna od obecnej. Mandat oddziałów europejskich wygasł w 2014 r. W krótkim horyzoncie czasowym polityka państw Starego Kontynentu będzie skoncentrowana na wycofywaniu własnych jednostek militarnych $\mathrm{z}$ regionu. $\mathrm{Z}$ dużym prawdopodobieństwem można stwierdzić, że w następstwie zainteresowanie bezpieczeństwem i stabilnością regionu ze strony wielu podmiotów w ramach UE drastycznie spadnie. W tym samym czasie zagrożenia stabilności regionu pozostaną jednak w dużej mierze niezmienione. O ile przeniesienie konfliktu z Afganistanu do Azji Środkowej zdaje się już relatywnie mało prawdopodobne, jak zaznaczono wcześniej, w ramach dyskusji nad bezpieczeństwem nie podjęto żadnych kroków mających rozwiązać istniejące zagrożenia endemiczne. USA w ramach inicjatywy „Nowy Jedwabny Szlak”, a Rosja w ramach nowych regulacji Organizacji Układu o Bezpieczeństwie Zbiorowym przygotowują się już do wzmocnienia służb granicznych państw regionu ${ }^{35}$.

Proces wycofywania zachodnich sił zbrojnych spowodował intensyfikację bilateralnych i wielostronnych działań dyplomatycznych w regionie. Trzeba przyznać, że o wiele większą aktywność niż UE w tym zakresie wykazują Chiny, Rosja, Iran, państwa Zatoki Perskiej, Pakistan, Turcja i wciąż USA. Inicjatywy regionalne podejmują również rozliczne organizacje międzynarodowe: Szanghajska Organizacja Współpracy, OBUZ, Unia Eurazjatycka czy Celna, Proces Stambulski itd. Dynamika ich wzajemnych relacji może, choć nie musi, położyć kres pojęciu poradzieckiej Azji Środkowej - państwa kręgu kultury perskiej: Tadżykistan i Uzbekistan znajdują się pod większym wpływem państw muzułmańskich niż tureckojęzyczne i relatywnie bardziej zrusyfikowane Kazachstan, Kirgistan i Turkmenistan. Jednocześnie pamięć czasów radzieckich zaczyna słabnąć - wszystkie państwa regionu mogą się pochwalić przewagą ludności poniżej 30 roku życia. Wiele wskazuje, że postrzeganie państw regionu w kategoriach jednolitego bloku republik poradzieckich specyficzne dla lat 90. ubiegłego stulecia powoli odchodzi w przeszłość.

Razem z jednolitymi ujęciami poradzieckiej Azji Środkowej powoli w przeszłość odchodzą też przywódcy, którzy ją tworzyli. Dotychczas strategia UE była zakorzeniona

${ }^{35}$ F. Indeo, Central Asia beyond 2014: Building Regional Security Architecture, „ISPI Analysis” June 2014, No. 262. 
w realiach autokratycznych rządów przywódców politycznych pamiętających czasy radzieckie. W dużej mierze wiązało się to z zaakceptowaniem ich koncepcji bezpieczeństwa regionu - negującej endemiczny charakter niepokojów społecznych. Jednakże formuła stabilności opartej na twardych rządach doświadczonych polityków poradzieckich chyli się ku końcowi. Większość państw w regionie czeka proces sukcesji władzy, co może oznaczać lokalne reorganizacje elit politycznych i gospodarczych, w szczególności w Kazachstanie, Uzbekistanie i Tadżykistanie, których prezydenci pamiętają początki niepodległej państwowości ${ }^{36}$. Proces ten niekoniecznie musi przebiegać spokojnie i pokojowo. Polityczna niestabilność Kirgistanu w latach 2005 i 2010 jest najlepszym przykładem, do czego może prowadzić niekontrolowany upadek lokalnego reżimu. Narastające napięcia polityczne w Tadżykistanie, wynikające z powolnego przedawniania się umowy społecznej, która zakończyła wojnę domową w latach 90. ubiegłego wieku, są nie mniejszym powodem do niepokoju. Protesty i wystąpienia społeczne w 2011 r. w Kazachstanie, zbieżne w czasie z pogorszeniem zdrowia prezydenta N. Nazarbajewa, to kolejne zapowiedzi możliwej eksplozji po jego odejściu od władzy ${ }^{37}$. Potencjalne napięcia społeczne na tle zmiany ekip rządzących mogą wykazać tendencje do rozprzestrzeniania się na państwa sąsiedzkie poprzez migracje uchodźców, wciąż żywe powiązania klanowe czy etniczne, sieci przestępcze, zbrojne podmioty niepaństwowe.

W cieniu zmiany równowagi militarnej region doświadcza nie mniej istotnych, choć trudniej zauważalnych przemian na rynku surowców energetycznych, zwłaszcza związanych z upowszechnieniem nowych metod wydobycia gazu ziemnego oraz technologii LNG. W przyszłości mogą się one przełożyć na jakościową zmianę atrakcyjności regionu dla podmiotów zewnętrznych. Wzrost podaży gazu łupkowego połączony z liberalizacją amerykańskiego rynku gazu ziemnego i większą dostępnością błękitnego paliwa w wersji skroplonej może spowodować, że inwestycyjnie złoża Azji Środkowej pozostaną interesujące wyłącznie w ramach portfeli paliwowych ich bezpośrednich sąsiadów. Tylko oni bowiem będą w stanie zabezpieczyć dostawy rurociągami w regionie zagrożonym wysoką aktywnością zbrojnych podmiotów niepaństwowych. Doświadczenie ostatnich dwudziestu lat wskazuje również duży potencjał konfliktów między państwami tranzytowymi, który często stawia odleglejszych terytorialnie odbiorców w politycznie i ekonomicznie niepewnej

36 Emomali Rachmon, prezydent Tadżykistanu, objął władzę w połowie lat 90. - w trakcie wojny domowej, co nie zmienia faktu, że stażem jako głowa państwa ustępuje N. Nazarbajewowi (Kazachstan) i I. Karimowi (Uzbekistan) zaledwie trzy lata.

37 J. Boonstra, Democracy in Central Asia: Sowing in Unfertile Fields?, „EUCAM Policy Brief” 2012, No. 23 
sytuacji ${ }^{38}$. Jednocześnie zarówno w wymiarze cen, jak i transportu gaz ziemny stanie się dla państw zachodnich łatwiej dostępny z geograficznie odmiennych źródeł. Przy rosnącym popycie ze strony ChRL, a w przyszłości być może również Indii, ograniczanie podaży surowców energetycznych w Azji Środkowej przez USA czy UE zmusi wymienione państwa rozwijające się do ich pozyskiwania z rynków łatwiej dostępnych państwom zachodnim. Rozwiązanie takie wydaje się ekonomicznie nieatrakcyjne dla obu stron. $Z$ tego powodu w perspektywie dekady można się spodziewać postępów w substytucji przez rynki zachodnie zwłaszcza gazu z Azji Środkowej surowcem $\mathrm{z}$ innych źródeł.

Każdy podmiot polityczny zainteresowany obecnością w Azji Środkowej musi zdawać sobie sprawę nie tylko ze złożoności jej historii najnowszej, ale również wyzwań, jakie niesie dla niej przyszłość. W rzeczywistości politycznej zdominowanej przez autorytarne rządy już jeden $\mathrm{z}$ wymienionych czynników może spowodować poważne wstrząsy w skali regionu. Powaga sytuacji wynika z faktu, że w nadchodzących latach mogą one współwystępować i efektem synergii wywołać falę niepokoi społecznych sięgających poza jego granice, np. do chińskiego Xinjiangu czy na północny lub południowy Kaukaz. Dla wielu politologów dynamika polityczna Azji Środkowej jest fascynująca. Polityków przyprawia jednak często o ból głowy. Jeśli UE chce być aktywnym podmiotem w Azji Środkowej, kontynuacja dotychczasowego podejścia nie powinna być brana pod uwagę.

\section{Strategia UE wobec Azji Środkowej - perspektywy}

Strategia została sformułowana w okresie, kiedy członkowie Unii byli przekonani o dużych możliwościach sformułowania efektywnej unijnej polityki zagranicznej. Rozczarowanie praktyką polityczną po Traktacie lizbońskim, niepowodzenia UE w ramach reakcji wobec Arabskiej Wiosny, pogarszająca się sytuacja na Ukrainie oraz postępujące oziębienie relacji z Rosją znacząco stonowały takie przekonania. W kontekście Azji Środkowej szczególnie rosnące ambicje odbudowy regionalnych wpływów przez prezydenta W. Putina mogą doprowadzić do napięć w polityce międzynarodowej, zwłaszcza biorąc pod uwagę rozszerzenia UE na Wschód na przestrzeni dwóch dekad po upadku ZSRR. Jeżeli dodać kryzys strefy euro po światowym

\footnotetext{
${ }^{38}$ Nie wspominając o politycznym traktowaniu dostaw surowców energetycznych przez Rosję, co już skłania wielu odbiorców europejskich do dodatkowego zwiększenia wysiłków prowadzących do dywersyfikacji dostaw, jak również zwiększenia roli odnawialnych źródeł energii we własnym bilansie energetycznym.
} 
kryzysie finansowym oraz głęboką introspekcję, w jaką popadły instytucje unijne, nie dziwi przesunięcie kwestii zagranicznych na plan dalszy, zwłaszcza w odniesieniu do odległego, mało znanego i zrozumiałego regionu świata. Rodzi to fundamentalne pytania: Po co UE ma kontynuować strategię w regionie o wątpliwych interesach dużej części swych członków? Dlaczego w ogóle UE miałaby angażować się w Azji Środkowej?

Jeśli Europa ma ambicje bycia graczem w polityce światowej, nie może sobie pozwolić na zupełne opuszczenie poradzieckiej Azji Środkowej. Rozciągając się pomiędzy zachodnimi Chinami, Indiami, Pakistanem i Iranem, Morzem Kaspijskim i Rosją, jest to region, w którego sąsiedztwie dynamicznie rozwijają się liczne procesy międzynarodowe, mogące w dużej mierze rzutować na sytuację globalną. Z pewnością nie będzie on obojętny dla przyszłości relacji wielkich mocarstw międzynarodowych, jak USA, Chiny i Rosja, i może odegrać istotną rolę w kształcie przyszłych sojuszy między nimi. Jeśli UE nie będzie przy nich obecna i ich świadoma, globalna rola Europy będzie mrzonką.

Kluczowa dla poprawienia efektywności działań unijnych w Azji Środkowej jest rewaluacja politycznych celów i instrumentów wykorzystywanych do ich osiągnięcia w kontekście bieżących, a nie historycznych wyzwań w regionie. $\mathrm{Z}$ pewnością potrzeba do tego większej precyzji, możliwe, że również mniej ambitnych, ale bardziej realnych celów i zadań. Unia Europejska musi przyjąć realistyczną perspektywę w zakresie swoich interesów oraz ich realizacji w Azji Środkowej. UE nie była i nie będzie jednym z głównych rozgrywających w regionie. Nie ma zasobów do zaangażowania się w kwestie twardego bezpieczeństwa, nie ma instrumentów do efektywnego udziału w geopolitycznych rozgrywkach energetycznych, nie dorównuje wpływami ani rozpoznaniem regionu Chinom, Rosji czy USA. Unia Europejska musi się pogodzić, że jej znaczenie będzie drugoplanowe. $Z$ tego powodu najwyższy czas uznać transformacyjne cele strategii za nietrafione i niewykonalne. Kurczowe trzymanie się nierealistycznych założeń de facto działa na szkodę w wyniku zbyt pobieżnej i szerokiej dystrybucji ograniczonych zasobów politycznych i finansowych, co przekłada się na nieefektywność ich alokacji.

Chociaż UE jest pomniejszym graczem w Azji Środkowej, nie powinna być graczem marginalnym. Nie może konkurować z Rosją, Chinami czy USA w geopolityce opartej o Hard Power. Może jednak budować pozycję w oparciu o swoje silne strony: promocję demoliberalnego ładu społecznego i demokratyzację oparte na efektywniejszym niż dotychczasowy systemie finansowania. Oznacza to potrzebę postawienia demokratyzacji i praw człowieka w centrum politycznych działań i porzucenia asymetrycznej formuły dialogu $\mathrm{z}$ autorytarnymi reżimami maksymalizującymi użyteczność współpracy z UE kosztem wiarygodności międzynarodowej instytucji 
europejskich. UE posiada duże doświadczenie w pomocy rozwojowej i lepszą niż siedem lat temu znajomość regionu. Oznacza też porzucenie większości planów dotyczących pozyskiwania surowców energetycznych z regionu. Doświadczenia mijającego ćwierćwiecza sugerują, że Europa dysponuje bardziej stabilnymi i bliższymi ich źródłami, a zmiany zachodzące na rynkach energetycznych oraz upowszechnianie się odnawialnych źródeł energii może się efektywnie przyczynić do substytucji węglowodorów Azji Środkowej już w perspektywie średniookresowej. W dłuższej perspektywie z kolei pomoże to w promocji UE w regionie i zdystansuje Europę od zarzutów o oportunizm i politykę podwójnych standardów wobec lokalnych autokratów w zamian za ich otwarcie na współpracę energetyczną.

Elity polityczne Azji Środkowej stąpają po kruchym lodzie autorytaryzmu w regionie będącym polem rozgrywki kluczowych dla ładu globalnego mocarstw międzynarodowych. Z perspektywy Unii Europejskiej faworyzowanie reżimów, które obecnie są u władzy, a w przyszłości mogą ją w niekontrolowany przez Europę sposób stracić, co wcale nie musi się wiązać $\mathrm{z}$ demokratyzacją państw regionu, jest nie tylko marnowaniem zasobów politycznych, ale również dużym ryzykiem wizerunkowym. Siedem lat obowiązywania strategii UE wobec Azji Środkowej przyniosło zbyt dużo rozczarowań, by kontynuować ją w obecnym kształcie. Jeżeli instytucje unijne nie pochylą się nad jej głęboką reformą, dalsze prowadzenie działań w obecnej formule będzie niczym innym jak marnowaniem ich politycznego potencjału.

\section{Literatura}

Axyonova V., EU Human Rights and Democratization Assistance to Central Asia: In Need of Further Reform, „EUCAM Policy Brief” 2012, No. 22.

Boonstra J., Democracy in Central Asia: Sowing in Unfertile Fields?, „EUCAM Policy Brief” 2012, No. 23.

Boonstra J., EU Central Asia Policy: Steady as She Goes, „Central Asia Policy Brief” August 2012, No. 4.

Boonstra J., Is the EU Downscaling Political Engagement in Central Asia?, „EUCAM Commentary" February 2014, No. 23.

Collins K., Clan Politics and Regime Transition in Central Asia, Cambridge University Press, New York 2006.

Cooley A., The New Great Game in Central Asia: Geopolitics in a Post-Western World, „Foreign Affairs” 2012, No. 4.

Corruption Perceptions Index, Transparency International dla Azji Środkowej: http:// www.transparency.org/research/cpi/ 
Falkowski M., Tadżykistan w obliczu kryzysu państwowości, „Komentarze OSW” 2009, nr 22.

Freedom House Countries in Transition, Azja Centralna: http://www.freedomhouse. org/regions/eurasia\#.VARkx6OTCSo (1.09.2014).

Gacek Ł., Azja Centralna w polityce energetycznej Chin, Wydawnictwo UJ, Kraków 2013.

Gavrilis G., Central Asia's Border Woes \& the Impact of International Assistance, Central Eurasia Project, Open Society Foundation, New York, May 2012.

Indeo F., Central Asia beyond 2014: Building Regional Security Architecture, „ISPI Analysis" June 2014, No. 262.

Jarosiewicz A., Strachota K., Nowa Wielka Gra - przesilenie?, „Komentarze OSW” 2009, nr 26.

Kozłowski K., Iluzje rewolucji. Rewolucja róż, rewolucja pomarańczowa, rewolucja tulipanów, Oficyna Wydawnicza SGH, Warszawa 2010.

Kozłowski K., Kolory Rewolucji, Poltext, Warszawa 2012.

Kozłowski K., Rewolucja Tulipanów. Geneza, przebieg, konsekwencje, Elipsa, Warszawa 2009.

Melvin N., The EU Needs a New Value-Based Realism for its Central Asia Strategy, „EUCAM Policy Brief" 2012, No. 28.

The not so welcome guest: Who invited Islam Karimov to Brussels?, „The European Voice” 7 January 2011, http://www.europeanvoice.com/article/imported/the-not-sowelcome-guest/70077.aspx

Oficjalna Witryna Trans-European Energy Network: http://ec.europa.eu/energy/infrastructure/index_en.htm, Nabucco opatrzono symbolem NG3.

Olcott M.B., Islam and Fundamentalism in Independent Central Asia, w: Muslim Eurasia: Conflicting Legacies, red. R. Yaakov, Frank Cass, London 1995.

Rashid A., The New Great Game - The Battle for Central Asia's Oil, „Far Eastern Economic Review" 10 April 1997.

Ross W., Stosunki chińsko-rosyjskie. Historia, współczesność, perspektywy, w: Chińska Republika Ludowa we współczesnych stosunkach międzynarodowych, red. P. Ostaszewski, Oficyna Wydawnicza SGH, Warszawa 2011.

Sprawozdanie w sprawie postępów w realizacji Strategii UE wobec Azji Środkowej, http:// www.europarl.europa.eu/sides/getDoc.do?pubRef=-//EP//TEXT+REPORT+A7-2011 $-0338+0+\mathrm{DOC}+\mathrm{XML}+\mathrm{V} 0 / / \mathrm{PL}$

Strachota K., Kaukaz Poludniowy i Azja Centralna po wojnie rosyjsko-gruzińskiej - konsekwencje geopolityczne, „Komentarze OSW” 25 września 2008, nr 10, http://www.osw.waw.pl/ pl/publikacje/komentarze-osw/2008-09-25/kaukaz-poludniowy-i-azja-centralnapo-wojnie-rosyjsko-gruzinski

World Press Freedom Index dla Azji Środkowej, Reporterzy bez Granic: http://rsf. org/index2014/en-eastern-europe.php

Zapaśnik S., Demokracja a kultury tradycyjne w Azji Środkowej, w: Jednostka i społeczeństwo w Azji Wschodniej, red. A.W. Jelonek, Wydawnictwo Adam Marszałek, Toruń 2007. 


\section{EU Central Asia policy: Analysis of effectiveness of EU - Central Asia New Partnership Strategy}

The study concerns the effectiveness of EU Post-Soviet Central Asian policy. The analysis of the EU strategy leads to two questions: why and how EU wants to engage this politically challenging region in the Post-Soviet Space. Regardless of satisfaction of EU bureaucracy with at best mediocre effects of undertaken actions, independent analysts perspective leads to a conclusion that EU does not use its own potential in the most effective way and its activity is sometimes more damaging than productive in terms of managing own assets as well as building its international reputation.

Keywords: EU foreign policy, Post-Soviet Central Asia, Energy Politics

\section{La politique de l'UE en Asie centrale: I'analyse de l'efficacité de la stratégie de I'UE pour un nouveau partenariat avec l'Asie centrale}

L'étude porte sur l'efficacité de la politique de l'UE en Asie centrale post-soviétique. L'analyse de la stratégie de l'UE pose deux questions: pourquoi et comment l'UE veut engager cette region politiquement difficile dans l'ère post-soviétique. Indépendamment de la satisfaction de la bureaucratie de l'UE avec, au mieux, de effets médiocres des actions menées, la perspective des analystes indépendants conduit à la conclusion que l'UEn'utilise pas son potentiel de manière efficace, et son activitéest parfois plus dommageable que productive dans la gestion de ses propresatouts et dans la construction de sa réputation internationale.

Mots-clés: la politique étrangère de l'UE, l'Asie centrale post-soviétique, la politique de lénergie

\section{Политика ЕС в Центральной Азии: анализ эффективности Стратегии нового партнерства между ЕС и Центральной Азией}

Исследование относитсяк эффективности политики ЕС в постсоветскойЦентральной Азии. Анализ стратегии ЕС приводит к двум вопросам: почему и как ЕС хочет втягиваться в этотполитическисложныйрегион 
постсоветского пространства? Несмотря на удовлетворение бюрократов ЕС, получаемые от, в лучшем случае заурядных, результатов предпринятых действий, независимые аналитики приходят к выводу, что ЕС не использует самым эффективным способом свой потенциал, а его деятельность иногда приносит больше вреда, чем пользы в отношении управления собственными активами иукрепления международной репутации.

Ключевые слова: внешняя политика ЕС, постсоветскаяЦентральная Азия, энергетическая политика 